\title{
A RESPONSABILIDADE CIVIL DO ARREMATANTE PELO PASSIVO AMBIENTAL NAS EXECUÇÕES CIVIS: A MÁXIMA EFETIVIDADE NA TUTELA DE DIREITOS FUNDAMENTAIS
}

CIVIL RESPONSIBILITY OF THE WINNING BIDDER FOR THE ENVIRONMENTAL LIABILITIES IN CIVIL EXECUTIONS: MAXIMUM EFFECTIVENESS IN THE PROTECTION OF ESSENTIAL RIGHTS

LA RESPONSABILIDAD CIVIL DEL REMATANTE POR EL PASIVO AMBIENTAL EN LAS EJECUCIONES CIVILES: LA MÁXIMA EFECTIVIDAD EN LA TUTELA DE DERECHOS FUNDAMENTALES

Jaqueline Mielke Silva ${ }^{1}$

1 Doutora e Mestre em Direito pela Universidade do Vale do Rio dos Sinos - UNISINOS; Especialista em Direito Processual Civil pela Pontifícia Universidade Católica do Rio Grande do Sul - PUC/RS; Professora dos cursos de pós-graduação stricto sensu e lato sensu da Faculdade Meridional - IMED; Professora da Faculdade Inedi - CESUCA; Professora em cursos de pósgraduação da Universidade de Caxias do Sul - UCS, Universidade de Santa Cruz - UNISC, Universidade Ritter dos Reis - UNIRITTER, Universidade de Chapecó - UNOCHAPECÓ, Faculdade IDC, dentre outras; Professora na Escola Superior da Magistratura do RS - AJURIS, Escola Superior da Magistratura Federal - ESMAFE, Fundação Escola Superior do Ministério Público - FMP, Fundação Escola Superior da Magistratura do Trabalho - FESDEP. Advogada. 
Resumo: Em prol da efetivação da proteção ao meio ambiente, em algumas situações haverá a incidência da responsabilidade civil sobre pessoa que não causou o risco ou o dano ambiental, como é o caso de adquirente de imóvel em reserva florestal desmatada pelo antigo proprietário. Assim, a interpretação que deve ser dada ao artigo $2^{\circ} \S 2^{\circ}$ da Lei $12.651 / 12$ deve ser no sentido de interpretar-se a expressão "sucessão" em sentido amplo, abrangendo também as aquisições em sede de arrematação, preservando-se assim o direito fundamental ao meio ambiente equilibrado.

Palavras-chave: Arrematação. Dano ambiental. Responsabilidade civil.

Abstract: In the attempt to make environmental protection effective, in some situations civil liability will fall upon an individual who did not cause the environmental risk or damage, as in the case of the buyer of property in a forest reserve that was deforested by the previous owner. Thus, in section 2, paragraph 2 of Law 12,651/12, the term "succession" must be interpreted in a broad sense, also encompassing purchases made in auctions, in order to preserve the essential right to a balanced environment.

Keywords: Auction. Environmental damage. Civil responsibility.

Resumen: En favor de la eficacia de la protección al medio ambiente, en algunas situaciones habrá incidencia de la responsabilidad civil sobre la persona que no causó el riesgo o el daño ambiental, como es el caso del adquiriente de inmueble en reserva forestal desmatada por el antiguo propietario. De este modo, la interpretación que debe ser dada al artículo $2^{\circ} \S 2^{\circ}$ de la Ley 12.651/12 debe ser en el sentido de interpretar la expresión "sucesión" en sentido amplio, abarcando también las adquisiciones en sede de remate, preservándose así el derecho fundamental al medio ambiente equilibrado.

Palabras clave: Remate. Daño ambiental. Responsabilidad civil. 


\section{INTRODUÇÃO}

O Código Florestal ${ }^{2}$ estabeleceu a natureza propter rem para as obrigações decorrentes de danos ambientais. Consequentemente, o sucessor - de qualquer natureza -, no caso de transferência do domínio ou posse do imóvel, também responderá pelo passivo ambiental.

A extensão da responsabilidade civil pela reparação do dano ambiental para o arrematante é um tema que ainda não foi objeto de análise no âmbito do direito brasileiro. Se, de um lado, muitos afirmam tratar-se a arrematação de aquisição de propriedade a título originário, de outro, há posicionamentos no sentido de que se trata de aquisição a título derivado. A adoção de um ou outro entendimento conduzirá à conclusão diversa, consoante será exposto nos capítulos subsequentes. A abordagem se torna ainda mais complexa nos casos em que o dano ambiental é oculto, em razão da boa-fé do terceiro adquirente.

Evidentemente, que a temática objeto do presente artigo, não pode ser analisada apenas a partir da natureza jurídica da aquisição em sede de arrematação, mas também de acordo com a Constituição Federal.

A perspectiva objetiva dos direitos fundamentais apresenta-se como a melhor alternativa para o enfrentamento da questão. Os direitos fundamentais transformam-se em princípios superiores, na condição de componentes estruturais da ordem jurídica, produzindo eficácia dirigente para o Estado e também em relação aos particulares. É a partir deste enfoque que o presente artigo se propõe a analisar a responsabilidade civil do arrematante pela reparação do dano ambiental. 


\title{
O CONSTITUCIONALISMO ECOLÓGICO EM CONSTRUÇÃO: O MEIO AMBIENTE EQUILIBRADO COMO DIREITO FUNDAMENTAL E A RELEVÂNCIA DOS PRINCÍPIOS DA PREVENÇÃO E DA PRECAUÇÃO
}

O status de direito fundamental do meio ambiente: ao lado dos direitos sociais - direitos fundamentais de segunda dimensão -, emergiram os chamados direitos de terceira dimensão ${ }^{3}$, que, segundo Norberto Bobbio4, "constituem uma categoria, para dizer a verdade, ainda excessivamente heterogênea e vaga, o que nos impede de compreender do que efetivamente se trata". O mais importante desses direitos é o reivindicado pelos movimentos ecológicos: o direito de viver em um meio ambiente equilibrado. Segundo Celso Lafer ${ }^{5}$,

\begin{abstract}
Os direitos de terceira geração, que materializam poderes de titularidade coletiva atribuídos genericamente a todas as formações sociais, consagram o princípio da solidariedade e constituem um momento importante no processo de desenvolvimento, expansão e reconhecimento dos direitos humanos, caracterizados, enquanto valores fundamentais indisponíveis, pela nota de uma essencial inexauribilidade, consoante proclama o autorizado magistério doutrinário.
\end{abstract}

3 Ao longo dos anos, os direitos fundamentais passaram por diversas transformações, tanto no que se refere ao seu conteúdo, quanto à sua titularidade, eficácia e efetivação. Tradicionalmente, costuma-se falar em três "gerações" de direitos. Todavia, há quem defenda a existência de uma quarta "geração" (Vide: BONAVIDES, Paulo. Curso de Direito Constitucional, p. 524-6). Ingo Wolfgang SARLET (A eficácia dos direitos fundamentais - Uma teoria geral dos direitos fundamentais na perspectiva constitucional. Porto Alegre: Livraria do Advogado, 2012, p. 47) faz uma crítica à expressão "geração", sugerindo a utilização da palavra "dimensão", verbis: "Num primeiro momento, é de se ressaltarem as fundadas críticas que vêm sendo dirigidas contra o próprio termo 'gerações' por parte da doutrina alienígena e nacional. Com efeito, não há como negar que o reconhecimento progressivo de novos direitos fundamentais têm o caráter de um processo cumulativo, de complementaridade, e não de alternância, de tal sorte que o uso da expressão 'gerações' pode ensejar a falsa impressão da substituição gradativa de uma geração por outra, razão pela qual há quem prefira o termo 'dimensões' dos direitos fundamentais, posição esta que aqui optamos por perfilhar, na esteira da mais moderna doutrina. Neste contexto, aludiu-se, entre nós, de forma notadamente irônica, ao que se chama de 'fantasia das chamadas gerações de direitos', que, além da imprecisão terminológica consignada, conduz ao entendimento equivocado de que os direitos fundamentais se substituem ao longo do tempo, não se encontrando em permanente processo de expansão, cumulação e fortalecimento".

4 BOBBIO, Norberto. A Era dos Direitos. 10. ed. Rio de Janeiro: Campus, 1992, p. 06.

5 LAFER, Celso. A reconstrução dos direitos humanos: um diálogo com o pensamento de Hannah Arendt. São Paulo: Companhia das Letras, 1998, p. 150. 
Assim, como direito de terceira dimensão, o direito fundamental ao meio ambiente ecologicamente equilibrado é inspirado no ideal de fraternidade, como forma de interligar os valores proclamados nas dimensões anteriores - direito de primeira dimensão (direitos civis e políticos) e direito de segunda dimensão (econômicos, sociais e culturais).

Nesse contexto, e já no âmbito da consagração normativa da proteção ambiental como direito humano e fundamental, no âmbito internacional ${ }^{6}$, a Declaração de Estocolmo das Nações Unidas sobre Meio Ambiente Humano7, de 1972, apresenta-se com o marco histórico-normativo inicial da proteção ambiental, projetando-se pela primeira vez no horizonte jurídico, especialmente no âmbito internacional, a ideia em torno de um direito humano a viver em um ambiente equilibrado e saudável, tomando a qualidade do ambiente como elemento essencial para uma vida humana com dignidade e bem-estar. Esse marco jurídico internacional de proteção do meio ambiente resultou consolidado na Declaração de Estocolmo, de 1992, por ocasião da Conferência das Nações Unidas (Eco-92), em que resultou proclamada a Declaração do Rio de Janeiro sobre Meio Ambiente e Desenvolvimento, que consigna, no seu Princípio $1^{\circ}$ que "os seres humanos estão no centro das preocupações com o desenvolvimento sustentável. Tem direito a uma vida saudável e produtiva em harmonia com a natureza". Por fim, a Declaração e Programa de Ação de Viena (1993) ressaltou que o direito ao desenvolvimento deve satisfazer as necessidades ambientais e de desenvolvimento das gerações presentes e futuras ${ }^{8}$.

A Constituição Federal de 1988 (art. 225 e art. $5^{\circ} \S 2^{\circ}$ ), seguindo o direito internacional e o direito comparado ${ }^{9}$, atribuiu ao meio ambiente o status de 6 Sobre o tema, vide: CANÇADO TRINDADE, Antônio Augusto. Direitos humanos e meio ambiente: paralelo dos sistemas de proteção internacional. Porto Alegre: Fabris, 1993.

7 Já no preâmbulo encontra-se o registro de que ambos os aspectos do ambiente, natural ou construído, são essenciais ao bem-estar e ao gozo dos direitos humanos básicos, com destaque para o direito à vida, compreendido como um direito à vida condigna e saudável. De acordo com o Princípio $1^{\circ}$, "o homem tem o direito fundamental à liberdade, igualdade e adequadas condições de vida, num meio ambiente cuja qualidade permita uma vida digna e bem-estar, e tem a solene responsabilidade de proteger e melhorar o meio ambiente, para a presente e as gerações futuras".

8 Neste sentido: SARLET, Ingo Wolfgang; FENSTERSEIFER, Tiago. Direito Constitucional Ambiental - Constituição, Direitos Fundamentais e Proteção do Ambiente. 4. ed. São Paulo: Editora Revista dos Tribunais, 2014, p. 49-50.

9 Nesse sentido: GAVIÃO FILHO, Anízio Pires. Direito Fundamental ao Ambiente. Porto 
direito fundamental ${ }^{10}$, em sentido formal e material ${ }^{11}$, revelando-se como uma

Alegre: Livraria do Advogado, 2005, p. 21-22: "O primeiro passo efetivamente institucional e global relativo à preocupação com o meio ambiente deu-se com a Declaração de Estocolmo sobre o Meio Ambiente Humano de 1972, na qual se proclamava ser a proteção do ambiente uma questão fundamental que afeta o bem-estar de todos os povos e o desenvolvimento econômico do mundo inteiro, constituindo-se em um desejo urgente dos povos e um dever de todos os governos. (...) Desde então, em nível das organizações internacionais, diversas iniciativas foram levadas a efeito no sentido da proteção ao ambiente, merecendo destacar-se a Declaração do Rio sobre o Meio Ambiente e Desenvolvimento de 1992, na qual se assentou, entre outros princípios, o de que os seres humanos estão no centro das preocupações com o desenvolvimento, tendo direito a uma vida saudável e produtiva em harmonia com a natureza. É a partir desse ingresso na pauta dos documentos internacionais que as questões relativas ao ambiente começam a receber normalização constitucional. (...) a partir da Constituição de Portugal de 1976, abriu-se uma segunda fase, com a consagração de um "direito ao ambiente" vinculado a um significativo conjunto de incumbências do Estado e da sociedade. Em realidade, o art. 31 da Constituição da Bulgária de 1971 já trazia norma no sentido de que a proteção e a salvaguarda da natureza e das riquezas das águas, do ar e do solo, assim como dos monumentos da cultura constituem uma obrigação para os órgãos do Estado, das empresas, das cooperativas e das organizações sociais, bem como um dever para todo cidadão. Da mesma forma, as normas dos arts. 24 e 25 da Constituição e os Cantões com vistas à proteção do homem e do ambiente contra as interferências nocivas. A Constituição do Panamá de 1972 apresentou um avançado ordenamento jurídico, incorporando a dimensão ambiental ao estabelecer normas como a do seu art. 110, segundo o qual é dever fundamental do Estado velar pela conservação das condições ecológicas, prevenindo a contaminação do ambiente e o equilíbrio dos ecossistemas, em harmonia com o desenvolvimento econômico e social do país. Também o art. 57, alínea 2, da Constituição da Hungria de 1972, já configurava como direito do cidadão a proteção do ambiente humano. A Constituição da Grécia de 1975 já trazia uma regulação detalhada de várias questões ambientais, explicitando no seu art. 24, alínea 1, a obrigação de o Estado adotar medidas especiais, preventivas e repressivas, com o objetivo de proteção ao ambiente. A Constituição de Portugal de 1976, em seu art. 66, estabeleceu que todos são titulares do direito ao ambiente são e ecologicamente equilibrado, incumbindo ao Estado prevenir e combater a contaminação do ambiente, bem como promover a exploração racional dos recursos naturais e com isso favorecer a melhora progressiva da qualidade de vida dos portugueses. A Constituição da Espanha de 1978, ao tratar dos "direitos e deveres fundamentais" e dos "princípios orientadores da política social e econômica", em seu art. 45, estabeleceu a norma segundo a qual todos têm o direito a desfrutar de um ambiente adequado para o desenvolvimento da pessoa e, ao mesmo tempo, todos têm o dever de conservá-lo. Igualmente, definiu-se que os poderes públicos devem velar pela utilização racional dos recursos naturais com o fim de proteger e melhorar a qualidade de vida, defender e restaurar o ambiente, apoiando-se na solidariedade coletiva. A Constituição brasileira produziu a constitucionalização do ambiente por intermédio de uma normalização que não se distanciou muito dos modelos constitucionais acima referidos. (...)".

10 Neste sentido: CARVALHO, Délton Winter. Dano Ambiental Futuro - A responsabilização civil pelo risco ambiental. Porto Alegre: Livraria do Advogado, 2013, p. 44.

11 Neste sentido, o entendimento de MILARÉ, Édis. (In: Princípios fundamentais do direito do ambiente. Revista dos Tribunais, Ano 87. V. 756, Outubro de 1998, p. 54), verbis: "A par dos direitos e deveres individuais e coletivos elencados no art. 50, acrescentou o legislador constituindo, no caput do art. 225, um novo direito fundamental da pessoa humana, direcionado ao desfrute de condições de vida adequada em um ambiente saudável ou, na dicção da lei, ecologicamente equilibrado'. Esse novo direito fundamental, reconhecido pela Conferência das Nações Unidas sobre o Ambiente Humano de 1972 (Princípio 1), reafirmado pela Declaração do Rio sobre Meio Ambiente e Desenvolvimento de 1992 (Princípio 1) e pela Carta da Terra de 1997 (Princípio 4), vem conquistando espaço nas Constituições mais modernas, como, por exemplo, as de Portugal, de 1976, e Espanha, de 1978". 
nova função do Estado Democrático de Direito, denominada pela doutrina como Estado Democrático Ambiental ${ }^{12}$.

Diante do exposto, é perceptível que a Carta Magna ${ }^{13}$ não apenas constitucionalizou a proteção ao meio ambiente, como também elevou este bem jurídico ao patamar de direito fundamental à dignidade humana ${ }^{14}$.

Nasce, assim, o direito à proteção do ambiente, segundo o qual todos os indivíduos são titulares do direito ao ambiente ecologicamente equilibrado, sendo dever do Estado proteger estes titulares contra atos lesivos de terceiros sobre o bem jurídico ora tutelado. Nesse sentido, é fundamental a identificação e a discriminação de condutas e atos lesivos ao ambiente como crimes ambientais e infrações administrativas, passíveis, respectivamente, de sanções penais e administrativas.

E não só isso, esse dever de proteção do ambiente também gera ao Estado a obrigação positiva de criar e aplicar medidas que assegurem a utilização dos recursos ambientais de maneira sadia e ecologicamente equilibrada, em detrimento ao direito de propriedade ${ }^{15}$, o que será abordado no decorrer deste estudo, que tem o propósito de analisar a responsabilidade civil do arrematante nas execuções civis.

12 Paulo de Castro RANGEL (In: Concertação, Programação e Direito do Ambiente. Coimbra: Coimbra Editora, 1994, p. 33-34), ao tratar o tema, "aponta para um modelo de desenvolvimento económico-social que se poderá designar por desenvolvimento 'auto-sustentado' (ou 'equilibrado' ou, ainda, 'sustentável'), no qual a legítima aspiração ao 'pleno emprego' e ao 'bem-estar' (objectivo carreado para o catálogo constitucional pelo princípio do Estado Social) terá de ser compatibilizada (harmonizada, equilibrada) com as tradicionais garantias do processo público democrático e com as novas exigências de proteção do ambiente, assegurando ao cidadão não apenas (ou não tanto ....) condições para uma 'vida com nível', mas também condições para uma 'vida de qualidade'"'.

13 Entretanto, a Constituição Federal de 1988 não foi pioneira ao legislar sobre a proteção ao meio ambiente. A Lei Federal n. 6.938/81, no artigo 20, inciso II, instituiu a "Política Nacional do Meio Ambiente", estabelecendo que "o meio Ambiente é patrimônio público a ser necessariamente assegurado e protegido, tendo em vista o uso coletivo".

14 No mesmo sentido: DESTEFENNI, Marcos. A Responsabilidade Civil Ambiental e as Formas de Reparação do Dano Ambiental. São Paulo: Bookseller, 2005, p. 134.

15 GAVIÃO FILHO, Anízio Pires. Direito Fundamental ao Ambiente, p. 53. 


\section{OS PRINCÍPIOS DA PREVENÇÃO E DA PRECAUÇÃO E A RESPONSABILIDADE CIVIL OBJETIVA PELO}

DANO AMBIENTAL

Sendo o direito ao meio ambiente ecologicamente equilibrado um direito fundamental à dignidade da pessoa humana, evidente que a legislação brasileira preocupou-se em amparar este bem jurídico. Nesse contexto, há previsão legal quanto à responsabilidade civil pela reparação do dano ambiental, a qual possui duas funções: reduzir os riscos ambientais e incentivar as medidas de prevenção de danos ambientais. ${ }^{16}$

A responsabilidade civil, no âmbito do direito ambiental, está intimamente ligada, essencialmente, a dois princípios ambientais, quais sejam, o princípio da prevenção ${ }^{17}$ e o princípio da precaução. O primeiro princípio possui status global, pois é reconhecido e abarcado em todo o mundo, tendo em vista que certos danos ambientais são irreversíveis ${ }^{18}$ ao ambiente, o que demonstra a necessidade de atuação preventiva pelos Estados. ${ }^{19} \mathrm{O}$ mesmo opera com o objetivo de antecipar a ocorrência do dano ambiental na sua origem, evitando, assim, que o mesmo venha a ocorrer. Tudo isto em razão de suas causas já serem conhecidas em termos científicos ${ }^{20}$.

Em contrapartida, o princípio da precaução, é uma espécie de princípio da prevenção qualificado e mais desenvolvido, abrindo caminho para uma

16 Nesse sentido: BETIOL, Luciana Stocco. Responsabilidade civil e proteção ao meio ambiente. Saraiva, 2010, p. 133.

17 Para o Paulo Affonso Leme MACHADO (In: Direito ambiental brasileiro. 9. ed. São Paulo: Malheiros, 2001, p. 49), o princípio da prevenção está positivado, no âmbito da América Latina, a partir da Política Nacional do Meio Ambiente, especificamente no inciso III do artigo 90 da referida lei.

18 Por exemplo, a extinção de espécies da fauna e da flora, reforça a relevância de se adotarem medidas preventivas, impedindo e proibindo a adoção de determinadas práticas.

19 DESTEFENNI, Marcos. A Responsabilidade Civil Ambiental e as Formas de Reparação do Dano Ambiental. p. 138-139.

20 Neste sentido: SARLET, Ingo Wolfgang e FENSTERSEIFER, Tiago. Princípios do direito ambiental. p. 160. Seguindo a mesma linha de raciocínio, Paulo de Bessa ANTUNES (In: Direito ambiental. 11. ed. Rio de Janeiro: Lumen Juris, 2008, p. 45), leciona: "o princípio da prevenção aplica-se a impactos conhecidos e dos quais se possa, com segurança, estabelecer um conjunto de nexos de causalidade que seja suficiente para a identificação dos impactos futuros mais prováveis". 
nova racionalidade jurídica, mas abrangente e complexa, vinculando a ação humana presente a resultados futuros. Segundo Ingo Wolfgang Sarlet e Tiago Fensterseifer $^{21}$,

Isso faz com que o princípio da precaução seja um dos pilares mais importantes da tutela jurídica do ambiente e, consequentemente, seja reconhecido como um dos princípios gerais do Direito Ambiental moderno. O seu conteúdo normativo estabelece, em linhas gerais, que, diante da dúvida e da incerteza científica a respeito da segurança e das consequências do uso de determinada substância ou tecnologia, o operador do sistema jurídico deve ter como fio condutor uma postura precavida, interpretando os institutos jurídicos que regem tais relações sociais com a responsabilidade e a cautela que demanda a importância existencial dos bens jurídicos ameaçados (vida, saúde, qualidade ambiental e até mesmo, em alguns casos, a dignidade da pessoa humana), inclusive em vista das futuras gerações

A ausência de um conhecimento científico adequado para assimilar complexidade dos fenômenos ecológicos e os efeitos negativos de determinadas técnicas e substâncias empregadas pelo ser humano podem levar, muitas vezes, a situações irreversíveis do ponto de vista ambiental, como, por exemplo, a extinção de espécies da fauna e da flora, além da degradação de ecossistemas inteiros. O princípio da precaução opera justamente como um filtro normativo para prevenir tais situações, considerando a ausência de domínio científico em relação à determinada técnica ou substância.

Além destes princípios, que fundamentam a responsabilidade civil por dano ambiental, há também o princípio da responsabilidade em face das gerações presentes e futuras ${ }^{22}$. No direito brasileiro, o primeiro diploma legal que tratou de forma diferenciada a temática da responsabilidade pelos danos ao meio ambiente foi a Lei 6.453/77, que regulou a responsabilidade civil por danos nucleares e a responsabilidade criminal por atos relacionados com atividades nucleares. Referida legislação consagrou, ainda, tanto a responsabilidade civil de natureza objetiva independentemente da existência de culpa do operador da instalação nuclear

21 SARTE, Ingo Wolfgang; FENSTERSEIFER, Tiago. Princípios do direito ambiental. p. 164.

22 Annelise Monteiro STEIGLEDER (In: Responsabilidade civil ambiental. As dimensões do direito ambiental no direito brasileiro. 2. ed. Rev., Atual. e ampl., Porto Alegre: Livraria do Advogado, 2011, p. 156-157), por sua vez, entende que o conteúdo da função social da responsabilidade civil por dano material vincula os princípios da solidariedade e responsabilidade social, ampliando o instituto da responsabilidade civil tradicional do direito privado. 
- quanto a natureza solidária atribuída à mesma. Posteriormente, a Lei 6.939/81 (art. $14, \S 1^{\circ}$ ) consagrou a responsabilidade civil de natureza objetiva, em matéria ambiental. No âmbito deste cenário já consolidado, a Constituição Federal, no art. $225, \S 4^{\circ}$, aprimorou o regime jurídico até então vigente, "cristalizando a tríplice responsabilidade (administrativa, civil e penal) do poluidor pelo dano ambiental"2324.

Assim, em razão da interpretação não apenas extensiva, mas fundada na consecução de valores protegidos pela Carta Magna, a responsabilidade civil por dano ambiental é trazida pela doutrina como sendo objetiva, tendo como pressuposto a existência de uma atividade que gere riscos ou danos ao meio ambiente ${ }^{25}$.

Entretanto, a incidência da responsabilidade civil decorre da verificação de riscos da atividade e, o mais importante, do nexo de causalidade, pressuposto imprescindível a imputar a responsabilidade sobre o empreendedor independentemente de dolo ou culpa.

23 Neste sentido: SARLET, Ingo Wolfgang; FENSTERSEIFER, Tiago. Príncípios do direito ambiental. p. 81.

24 A responsabilização pelo dano ambiental ainda foi complementada pela Lei dos Crimes e Infrações Administrativas em Matéria Ambiental (Lei n. 9.605/98), inclusive no tocante à responsabilização penal da pessoa jurídica em decorrência da prática de crimes ambientais (art. $3^{\circ}$ ). Reforçando a responsabilidade civil em matéria ambiental, a Lei da Política Nacional de Resíduos Sólidos (Lei 12.305/2010) consagrou de forma expressa a responsabilidade compartilhada pelo ciclo de vida dos produtos (art. $6^{\circ}, \mathrm{VII}$ ).

25 No Direito lusitano, a respeito do tema, leciona Paula Meira LOURENÇO (In: A função punitiva da responsabilidade civil. Coimbra: Coimbra Editora, 2006, p. 322): "a defesa do ambiente encontra-se expressamente consagrada no art. 66 da CRP e na parte final da alínea a) do artigo $3^{\circ}$, da Lei de Bases do Ambiente (LBA), que estabelece o princípio do 'poluidor pagador', ou seja, que o poluidor é "obrigado a corrigir ou recuperar o ambiente, suportando os encargos daí resultantes, não Ihe sendo permitido continuar a acção poluente". A correção e inibição de condutas poluentes é uma das facetas mais interessantes do Direito do Ambiente, o que nos permite afirmar que é regido pelo princípio da prevenção, segundo o qual, nas palavras de MENEZES CORDEIRO: 'as medidas jurídicas a encarar não visam apenas a reparação dos danos; elas procurarão, antes, evitar que eles ocorram, uma vez que a sua integral reparação é, muitas vezes, impossível (sublinhado nosso). O princípio da prevenção afasta o dogma da função exclusivamente reparadora da responsabilidade civil, dogma que certamente contribuiu para a procura de soluções nos Direitos contra-ordenacional, penal e administrativo, originando a hipertrofia destes ramos de direito, e aobliteração de novas perspectivas do instituto da responsabilidade civil. Afirma MENEZES CORDEIRO que '(a) indemnização, para além dos fins clássicos assume, ainda, um papel duma pena, com um desempenho importante no já referido domínio da prevenção. A sua transposição ambiental é muito importante, tendo vindo a ser enfatizada. Portanto, parece-nos que o instituto da responsabilidade civil, através das suas funções preventiva e punitiva, pode consubstanciar uma solução possível para a resolução dos novos problemas que surgem em material de Direito do ambiente". 
E é exatamente no nexo de causalidade que reside a maior problemática à imputação da responsabilidade civil por dano ambienta ${ }^{26}$, especialmente quando há pluralidade de agentes que contribuíram para a degradação ambiental. Em muitos casos, o dano ambiental é de difícil individualização, em razão de seu caráter difuso. Neste caso, torna-se difícil a constatação da parcela de responsabilidade de cada um dos corresponsáveis, em consequência de uma lesão conjuntamente provocada. O dano ambiental poderá ter fontes múltiplas a ser proveniente de atividades conjuntas, sem que seja possível determinar com exatidão os responsáveis. A solidariedade passiva é a solução dada pela legislação ${ }^{27}$, jurisprudência e doutrina brasileiras $^{28}$. Segundo Délton Winter de Carvalho ${ }^{29}$,

Nestas hipóteses, haveria um conflito de interesses entre o direito à reparação integral, princípio geral em matéria ambiental, e a expectativa dos responsáveis por limitar sua responsabilidade, proporcionalmente, à fração de sua participação na consecução do evento lesivo ambiental em sua globalidade. A solução adotada pela doutrina brasileira é a adoção da regra da solidariedade passiva, em razão da conjugação dos elementos da pluralidade passiva, da indivisibilidade obrigacional oriunda do bem ambiental (em sua unidade de bem comum) e da responsabilização civil pelo risco.

26 Délton Winter de Carvalho (In: Dano Ambiental Futuro - A responsabilização civil pelo risco ambiental. Porto Alegre: Livraria do Advogado, 2013, p. 44) refere à impropriedade da incidência das teorias tradicionais sobre nexo causal em matéria ambiental, verbis: "as teorias tradicionais de interpretação e configuração subsuntiva do nexo causal apresentam uma relação muito próxima com a responsabilidade civil em sua formação subjetiva. Portanto, estas demonstram grande impropriedade para sua incidência aos casos de responsabilização civil por danos ambientais".

27 A Lei n. 6.938/81, nos artigos 30, inciso IV e 14, parágrafo primeiro, prevê a responsabilidade solidária, que descarta a vontade comum dos devedores pela reparação do dano ambiental.

28 A jurisprudência do Superior Tribunal de Justiça, de longa data, consoante demonstra acórdão da lavra do Ministro Antônio de Pádua Ribeiro (REsp 37354, Segunda Turma, j. 30.08.95), é no sentido da responsabilidade solidária pelo dano ambiental, verbis: "A ação civil pública pode ser proposta contra o responsável direto, contra o responsável indireto ou contra ambos, pelos danos causados ao meio ambiente. Trata-se de caso de responsabilidade solidária, ensejadora do litisconsórcio facultativo - CPC, art. 46, I - e não do litisconsórcio necessário - art. 47". No mesmo sentido, o entendimento doutrinário: ADAMEK, Marcelo Vieira Von. Passivo Ambiental. Direito ambiental em evolução - n. 2. Vladimir P. Freitas (Org.). 1. ed. $3^{a}$ tir., Curitiba: Juruá, 2002, p. 125; LEMOS, Patrícia Faga Iglecias. Direito Ambiental. Responsabilidade civil e roteção ao meio ambiente. 2. ed. Reformulada e atualizada da obra Responsabilidade civil por dano ao meio ambiente. São Paulo: Editora Revista dos Tribunais, 2008, p. 144; MONTENEGRO, Magda. Meio Ambiente e Responsabilidade Civil. São Paulo: IOB, Thomson, 2005, p. 64.

29 CARVALHO, Délton Winter. Dano Ambiental Futuro - A responsabilização civil pelo risco ambiental. p. 142-143. 
Ademais, pondere-se que a doutrina prevalecente reza que a solidariedade decorrente de dano ambiental independe de concerto prévio e indivisibilidade de conduta, dependendo apenas da causa plural para evento fático (dano).

É importante, ainda, salientar nesta discussão que no direito positivo brasileiro não existe relevância entre a causa principal e secundária do evento danoso para diminuir ou excluir o dever de ressarcir. Prevalecendo o sistema da solidariedade, é importante ressalvar que aquele que suportou isoladamente toda responsabilidade poderá se voltar contra os demais responsáveis via ação regressiva.

Relativamente ao nexo de causalidade propriamente dito, a doutrina contemporânea tem defendido o abrandamento do mesmo em matéria ambiental, fugindo dos limites restritos da quase certeza. Entende-se que se deva adotar a probabilidade séria, fundada na experiência e no apoio científico ${ }^{30}$.

Por outro lado, em prol da efetivação da proteção ao meio ambiente, em algumas situações haverá a incidência da responsabilidade civil sobre pessoa que não causou o risco ou dano ambiental, como é o caso de adquirente de imóvel em reserva florestal desmatada pelo antigo proprietário ${ }^{31}$. Anelise Monteiro Steigleder ${ }^{32}$, ao tratar do tema, leciona:

Finalmente, pode-se, ainda, argumentar que o nexo de causalidade

30 Segundo Délton Winter de CARVALHO (In: Dano Ambiental Futuro - A responsabilização civil pelo risco ambiental. p. 142-143), "em conformidade com Günter Teubner, a complexidade ambiental é incompatível, em muitos casos, com a individualização e a pessoalidade característica teoria tradicional da responsabilidade civil. A configuração de 'unidades coletivas' produtoras de riscos ambientais (risk pools) justificariam o abrandamento ou mesmo o abandono do nexo causal para a imposição da responsabilização civil por danos ambientais, partir da coletivização da responsabilidade civil. A partir de perspectiva sistêmica (das atividades de risco) seria possível a formação de grupos corporativos de risco em detrimento do tratamento jurídico focado no individualismo da atribuição de responsabilidade civil tradicional. Isto seria possível a partir da configuração de uma estrutura unitária interna de 'cúpula', formada pelas atividades passíveis de terem ocasionado um determinado dano ambiental, cuja relação de causalidade seria demasiadamente difusa para a atribuição pessoalizada. Assim, a atribuição de responsabilidade civil ambiental seria deslocada da perspectiva do ator individual para centrar o foco na comunicação de risco. Estes grupos de risco ('risk pools') estariam sujeitos à responsabilização não apenas por suas falhas (individuais) em atender aos padrões ambientais, mas, também, por falhar em sua atuação cooperativa de gerenciamento coletivo de risco".

31 Neste sentido: LEMOS, Patrícia Faga Iglecias. Meio ambiente e responsabilidade civil do proprietário. São Paulo: Editora Revista dos Tribunais, 2008, p. 161.

32 STEIGLEDER, Annelise Monteiro. Responsabilidade Civil Ambiental - As dimensões do dano ambiental no Direito Brasileiro. p. 209. 
é um critério jurídico para a imposição do dever de reparar o dano, e o apego excessivo a tal requisito, em detrimento de princípios importantíssimos, como os princípios da prevenção, da precaução, do poluidor-pagador e da função social da propriedade, pode conduzir ao agravamento irremediável da condição ambiental de grandes áreas de terras.

Em síntese, com amparo nos diversos fundamentos expostos, o adquirente de um imóvel ambientalmente degradado poderá ser obrigado a preservá-lo, evitando o agravamento do dano ambiental, o que se justifica pela adoção dos princípios da prevenção, da precaução e do poluidor-pagador. Assim, a omissão do novo proprietário em conter a expansão do dano ambiental e repará-lo, cumprindo os deveres inerentes à função social de sua propriedade não deixa de ser lesiva ao meio ambiente, conforme dispõe o art. 225, § $3^{\circ}$, da Constituição Federal.

A autora ${ }^{33}$ sugere ainda, com o objetivo de assegurar ao adquirente proteção jurídica,

queo passivo ambiental seja averbadoà margem da matrículaimobiliária, o que pode ser determinado pelo órgão ambiental sobretudo no que se refere às áreas contaminadas por resíduos sólidos, diante do que prevê a Resolução 420/09 do CONAMA.

Evidentemente que, se o dano ambiental estiver averbado junto à matrícula do imóvel, preservada estará a boa-fé de terceiros adquirentes, sendo certo que os mesmos - nesta hipótese - não poderão alegar desconhecimento. Todavia, o grande problema ocorre naquelas hipóteses em que não constar na matrícula do imóvel o passivo ambiental ou, pior, naqueles casos em que o mesmo venha a ser oculto ou aparente, naquelas hipóteses de aquisição em hasta pública. Essa temática será mais bem abordada no próximo capítulo.

33 I STEIGLEDER, Annelise Monteiro. Responsabilidade Civil Ambiental - As dimensões do dano ambiental no Direito Brasileiro. p. 211. 


\section{A RESPONSABILIDADE CIVIL DO ARREMATANTE PELO PASSIVO AMBIENTAL APARENTE OU OCULTO NAS EXECUÇÕES CIVIS}

\section{A NATUREZA PROPTER REM DA OBRIGAÇÃO ORIGINÁRIA DO DANO AMBIENTAL}

A obrigação de natureza propter rem é um instituto jurídico consolidado no direito obrigacional, possuindo as seguintes características principais: a) relacionase ao titular de um direito real; b) o devedor se libera da prestação diante do abandono do bem, abdicando do direito real e c) são dotadas de acessoriedade especial $^{34}$. Segundo o civilista Caio Mário da Silva Pereira ${ }^{35}$,

Sem penetrarmos nas disputas de escolas, situamos a obligatio propter rem no plano de uma obrigação acessória mista. Quando a um direito real acede uma faculdade de reclamar prestações certas de uma pessoa determinada, surge para esta a chamada obrigação propter rem. É fácil em tese, mas às vezes difícil naquelas espécies que compõem a zona fronteiriça, precisar o seu tipo.

Mas, se há uma relaçãojurídico-real, em que se insere, adjeto à faculdade de não ser molestado, o direito a uma prestação específica, este direito pode dizer-se ad rem, e a obrigação correspondente é propter rem.

Não falta que lhe pretenda atribuir autonomia. Mas parece-os em vão, pois o direito que visa a uma prestação certa é de crédito, e a obrigação respectiva é estrita. A obligatio propter rem somente encorpa-se quando é acessória a uma relação jurídico-real ou se objetiva numa prestação

34 José de Oliveira ASCENÇÃO (In: As relações jurídicas reais. Lisboa: Livraria Morais, 1962, p. 139), ao tratar do tema, leciona: "obrigação propter rem entra na definição do próprio direito real que sobre a coisa se exerce: participa, pois, a realidade deste. Na obrigação propter rem encontra-se um simples débito, enquadrado no conteúdo dum direito real, e não um verdadeiro direito subordinado". Quanto à transmissibilidade, refere autor:

"(a) transmite-se automaticamente a todo o novo titular do direito real; b). é insuscetível de transmissão independente do direito real a que se refere".

35 PEREIRA, Caio Mário da Silva. Instituições de Direito Civil - Teoria Geral das Obrigações, VI. Atualizador: Guilherme Calmon Nogueira da Gama. Rio de Janeiro: Editora Forense, 2006, p. 48-49. 
devida ao titular do direito real, nesta qualidade (ambulat cum domino). E o equívoco dos que pretendem definir a obrigação propter rem como pessoal é o mesmo dos que lhe negam a existência, absorvendo-a na real. Ela é uma obrigação de caráter misto, pelo fato de ter como obligatio in personam objeto consistente em uma prestação específica; e como a obligatio in re estar sempre incrustada no direito real.

A partir do exposto, pode-se afirmar que o Código Florestal estabeleceu a natureza propter rem ${ }^{36}$ para as obrigações decorrentes de danos ambientais, de acordo com o previsto no artigo $2^{\circ}, \S 2^{\circ}$, verbis: "as obrigações previstas nesta Lei têm natureza real e são transmitidas ao sucessor, de qualquer natureza, no caso de transferência de domínio ou posse do imóvel rural".

No âmbito do direito ambiental, a obrigação propter rem é um instrumento que fortalece a função social da propriedade, bem como a proteção ao meio ambiente, pois estabelece uma relação de solidariedade entre o titular da propriedade e o autor do dano ambiental. Isso porque a obrigação propter rem decorre da própria condição da coisa, ou seja, do fato da propriedade ${ }^{37}$.

Entretanto, é equivocado pensar que a degradação anterior do meio ambiente desonera o causador do dano ambiental. Segundo Carlos Alberto de Salles ${ }^{38}$, o titular do domínio da coisa possui responsabilidade pelos danos decorrentes

36 Neste sentido o entendimento de Annelise Monteiro STEIGLEDER (Responsabilidade Civil Ambiental - As dimensões do dano ambiental no Direito Brasileiro. p. 211), verbis: "daí que se reconhece na obrigação de recuperar a área contaminada uma obrigação de natureza real - obrigação propter rem, que se integra no conteúdo do direito real de que é acessória. Esta espécie de obrigação situa-se numa zona cinzenta, entre o direito real e o direito obrigacional".

37 Nesse sentido, é o entendimento do Superior Tribunal de Justiça, conforme o trecho extraído do voto proferido pelo Relator Ministro Herman Benjamin (REsp. n. 948.921, disponibilizado no Diário da Justiça Eletrônico em 11.11.2009), verbis: "... consequentemente, as obrigações daí decorrentes trazem clara natureza propter rem (= em razão da coisa), isto é, aderem ao titular do direito real e acompanham os novos proprietários e possuidores ad infinitum, independentemente de sua manifestação de vontade, expressa ou tácita. Se a coisa muda de dono, muda, por igual e automaticamente, a obrigação de devedor, exista ou não cláusula contratual a respeito, cuide-se de sucessão a título singular ou universal. A rigor, não se deveria sequer falar em culpa ou nexo causal, quando o juiz exige do novo proprietário (e também do possuidor) comportamentos do tipo facere (averbação, recuperação com espécies nativas e defesa desses espaços) e non facere (abstenção de uso econômico direto - caso das APPs - e exploração com corte raso, já que admitido apenas o seletivo, quanto à Reserva Legal".

38 SALLES, Carlos Alberto de. A obrigação propter rem do proprietário pela recuperação do solo degradado. In: Francisco de Asís Palacios Criado, Marcelo Augusto Santana de Melo, Sérgio Jacomino. (Org.). Registro de imóveis e meio ambiente. São Paulo: Saraiva, 2010, p. 265-266. 
de sua propriedade, a qual se transfere junto com a transmissão da coisa. A transferência por meio de negócios jurídicos não acarreta a desoneração do poluidor, que é o causador direto do dano ambiental. Haverá a solidariedade da responsabilidade civil entre o proprietário e o degradador que causou o dano ambiental ${ }^{39}$.

Nesse sentido, é imperioso salientar que o interesse na preservação do meio ambiente é maior do que a preservação do patrimônio pessoal do proprietário (atual ou anterior) do imóvel, em virtude de um sopesamento de valores. Assim, o direito de propriedade encontra limite na função social da propriedade, de forma que aquele direito está funcionalizado pelo ambiente.

A partir da classificação da obrigação que decorre da propriedade ser de natureza propter rem, bem como pela possibilidade de responsabilização do novo proprietário do imóvel pelos danos ambientais causados anteriormente pelo antigo proprietário, surge a indagação: o arrematante responderá pelo passivo ambiental referente ao imóvel arrematado? A situação se revela ainda mais complexa nos casos de dano ambiental oculto ${ }^{40}$, em que o arrematante

39 Nesse sentido, é o entendimento do Superior Tribunal de Justiça, conforme o trecho extraído do voto proferido pela Rel. Min. Eliane Calmon (Resp. 1.056.540, disponibilizado no Diário da Justiça Eletrônico em 14.09.2009), verbis: "a possibilidade de responsabilizar o novo adquirente de imóvel já danificado, apenas busca dar maior proteção ao meio ambiente, tendo em vista a extrema dificuldade em precisar qual foi a conduta poluente e quem foi seu autor. Ressalta-se que a solidariedade nunca é presumida, mas decorre de lei ou da vontade das partes. No âmbito do Direito Ambiental, advém da diç̧ão dos arts. 30, inc. IV, e 14, § 10, da Lei 6.398/1981 (Lei da Política Nacional do Meio Ambiente), com redação nos seguintes termos: (...) Portanto, a responsabilidade por um dano recairá sobre todos aqueles relativamente aos quais se possa estabelecer um nexo de causalidade entre sua conduta ou atividade e o dano - com a ressalva da hipótese já mencionada -, ainda que não tenha havido prévio ajuste entre os poluidores. E, consoante o art. 942, caput, do atual Código Civil, a solidariedade pela reparação do dano alcança a todos, independentemente de ação conjunta. Uma vez estabelecida a solidariedade, cada obrigado é responsável pelo todo, podendo o titular do direito da ação exigir o cumprimento da obrigação de alguns dos devedores, de todos, ou daquele que gozar de melhor situação financeira, hábil a garantir a efetivação reparação do dano. Ressalva-se, nesse último caso, a possibilidade de mover ação regressiva contra os demais responsáveis na forma da lei. (...) In casu, o Tribunal de origem confirmou o teor da sentença de $1^{\circ} \mathrm{grau}$, que julgou procedente a demanda, para condenar as empresas - rés na ação -, solidariamente, a reparar o dano ambiental causado. Isso porque na hipótese em apreço, ficou comprovado que a empresa Furnas foi a responsável pelo ato lesivo ao meio ambiente, apesar de o imóvel já ser propriedade de outra pessoa jurídica, consoante se verifica pelo excerto seguinte do aresto recorrido (fl. 419): (...) Ora, se é possível a verificação do real causador do desastre ambiental, este necessariamente deve ser responsabilizado a reparar o dano, ainda que solidariamente com o atual proprietário do imóvel danificado".

40 Por exemplo, na hipótese de aquisição em hasta pública de uma área de terras em que 
desconhece os problemas ambientais envolvendo o imóvel, por ocasião da aquisição. Tanto a responsabilidade civil do arrematante pelo dano ambiental aparente quanto aquele que for oculto, serão abordados nos próximos itens.

\section{NATUREZA JURÍDICA DA ARREMATAÇÃO ${ }^{41}$}

O estudo a respeito da responsabilidade civil do arrematante pelo passivo ambiental exige a análise prévia da naturezajurídica da arrematação. Sem qualquer dúvida, trata-se de um tema que provoca acirrada divergência na doutrina clássica. Francesco Carnelutti ${ }^{42}$ sustenta a natureza contratual da alienação judicial, entendendo ser a mesma uma compra e venda em que o Estado substitui o vendedor, alienando em seu nome o bem ao arrematante. Nesta perspectiva, o Estado supriria a vontade do vendedor (do devedor ou do terceiro responsável), realizando a venda e recebendo o preço para, posteriormente, repassá-lo ao exequente. Segundo Luiz Guilherme Marinoni ${ }^{43}$,

esta explicação não convence, já que pressupõe a vontade do devedor de promover a alienação, o que certamente não existe. Para o autor, "os bens do devedor - diante de sua responsabilidade patrimonial - são sujeitos à execução, pouco importando a sua vontade, que nenhuma interferência tem sobre a alienação do bem penhorado. Na execução não há qualquer manifestação de vontade do proprietário da coisa 'forçadamente vendida', o que se exclui qualquer possibilidade de se pensar a alienação judicial como compra e venda. Assim, embora a alienação judicial possa ter alguma semelhança com o contrato de

tenham sido enterradas aparas de couro beneficiado (material esse que contém metais pesados, como, por exemplo, cromo e mercúrio, que são cancerígenos). O risco de aquisição de áreas com passivo ambiental oculto, em tese existe, e pode ocorrer. Todavia, exigir a realização de estudos de impacto ambiental em qualquer alienação judicial acabaria engessando as execuções civis.

41 Sobre expropriação, lecionam Giuseppe CAMPEIS e Arrigo de PAULI (In: Le esecuzioni civili - Procedimenti ordinary e speciali. Casi speciali di esecuzione. Padova_CEDAM, 1998 p. 43):

"L'espropriazione forzata à strumento posto a tutela del creditore di somme di denaro: essa consiste nel complesso degli atti diretti a trasformare I beni del debitore in denato, al fine di soddisfare il credito reprocedente (e glie ventuali intervenuti): non è quindi un'esecuzione in forma specifica, diretta sul benedovuto, ma ha carattere liquidativo e satisfattivo, a sanzione dell'inadempimento del debitore ad un obbligo resultante dal titolo".

42 CARNELUTTI, Francesco. Sistema de derecho procesal civil, Vol. 3, n. 437, p. 131-133. Tradução de Niceto Alcalá-Zamora y Castillo e Santiago Sentis Melendo. Buenos Aires: UTEHA, 1944, Vol. 3

43 MARINONI, Luiz Guilherme. Execução. São Paulo: Editora Revista dos Tribunais, 2007, p. 312. 
compra e venda, é de se perceber que os seus regimes jurídicos são evidentemente inconfundíveis ${ }^{44}$.

Giuseppe Chiovenda ${ }^{45}$ e Piero Calamandrei ${ }^{46}$ discordam da posição de Francesco Carnelutti. Os mesmos concedem a alienação judicial como um procedimento complexo, em que o Estado toma do devedor o poder de dispor da coisa penhorada. Assim, o Estado aliena o bem para terceiro, com o objetivo de satisfazer o direito de crédito do exequente. Pode afirmar que, em toda arrematação, há acordo de transmissão. O Estado transmite ao arrematante os direitos do executado na coisa penhorada, desde a assinatura do respectivo auto. O auto constitui o título substancial, que originará, mediante traslado, o título formal (carta de arrematação, em se tratando de bens em que haja a necessidade do instrumento formal à aquisição do domínio).

A diferença entre as teorias está que, na primeira, o Estado aliena o bem em nome do devedor, suprindo a sua vontade. Já, para a segunda, o Estado toma o poder de dispor o bem para aliená-1047.

Evidentemente que a alienação judicial não tem a natureza de compra e venda. Não se trata de um instituto de direito privado, mas sim de direito processual, decorrendo da atividade jurisdicional do Estado ${ }^{48}$.

Todavia, interessa identificar se o Estado transmite, originária ou a título derivado, a coisa. Luiz Guilherme Marinoni e Sérgio Cruz Arenhardt, ao tratarem do

44 No mesmo sentido, Salvatore PUGLIATTI (In: Esecuzione forzata e diritto sostanziale. Milano: Giuffrè, 1935 - XIII, p. 317) ao tratar do tema, leciona: "la vendita forzata, in quanto trasferimento coattivo, differisce circala natura giuridica dalla vendita volontaria. Differiscono anche, rispetto ala struttura, l'atto unilaterale in che la vendita forzata si sostanzia, dal negozio giuridico (bilaterale) in che si concreta la compra vendita. Naturalmente è logico suppore, in astratto, che questte differenze costitutive e strutturali possano anche riverberarsi sugli effeti: e la ricerca dev'essere appunto rivolta al fine dimettere in evidenzale concordanze e le di verngenzetra i du eschemi giuridice".

45 CHIOVENDA, Giuseppe. Sulla natura giuridica dell'espropriazione forzata, Saggi di diritto processuale civile, Milano: Giuffrè, 1993, Vol. 2, p. 459 e seguintes.

46 CALAMANDREI, Piero. La sentencia como acto de ejecución forzada, Estudios sobre el processo civil. Tradução de Santiago Sentis Melendo. Buenos Aires: EBA, 1945, p. 524527.

47 Enrico Tullio LIEBMAN (In: Processo de execução. São Paulo: Saraiva, 1968, p. 107), concebe a arrematação judicial como um vínculo de natureza de direito público.

48 Neste sentido: Salvatore SATTA (In: L'esecuzione forzata. 3. ed. Turim: UTET, 1954) e Luiz Guiherme Marinoni e Sérgio Cruz Arenhardt (In: Execução, p. 313). 
tema, referem tratar-se de aquisição a título derivado da propriedade ${ }^{49}$, verbis:

Trata-se, enfim, de figura distinta, não equiparada a qualquer outra. Tem natureza processual e constitui forma derivada de aquisição de propriedade. Por meio da expropriação, o Estado aliena bens do devedor (ou de terceiro responsável), ou ao menos limita o exercício de alguns poderes sobre tais bens (no caso do usufruto), no intuito de satisfazer o crédito exigido na execução. Constitui-se em procedimento complexo, formado ao menos por dois atos (o do Estado e o do adquirente), prevalecendo $o$ ato jurisdicional, por ser a causa eficiente da alienação.

O regime jurídico deste instituto não pode ser buscado nem no direito privado nem na disciplina da desapropriação, construindo-se a partir das regras processuais, dos princípios que regem a execução e dos direitos fundamentais processuais.

Por outro lado, há quem entenda tratar-se de aquisição originária da propriedade, desprezando-se o caráter negocial da arrematação ${ }^{50}$.

Entendemos com razão os primeiros. A aquisição em hasta pública por meio da arrematação se dá a título derivado e não originário pelas razões explicitadas.

\section{A PERSPECTIVA OBJETIVA DOS DIREITOS FUNDAMENTAIS E A SUA RELEVÂNCIA NA RESPONSABILIDADE CIVIL DO ARREMATANTE PELO DANO AMBIENTAL APARENTE OU OCULTO}

Problemática de alta relevância, ainda não tratada pela doutrina e jurisprudência em matéria ambiental, diz respeito à responsabilidade civil pelo dano ambiental aparenteou ocultonasaquisiçõesemhastas públicas realizadasnasexecuçõescivis ${ }^{51}$.

49 No mesmo sentido, o entendimento de Araken de ASSIS (In: Manual da Execução. 11. ed. São Paulo: Revista dos Tribunais, 2007, p. 665): "Por isso a arrematação implica aquisição derivativa e, cabendo a propriedade a terceiro, 'este não perdeu o seu direito', esclarece Liebman".

50 Neste sentido: Marco Tullio ZANZUCCHI. Diritto Processuale Civile. 4. ed. Milão: Giuffrè, 1946, Vol. 3, p. 101.

51 A título de ilustração, em outras hipóteses que contemplam obrigações propter rem, o Superior Tribunal de Justiça não tem responsabilizado o adquirente por dívidas inerentes à coisa adquirida em hasta pública. A primeira delas diz respeito a dívidas decorrentes de tributos devidos em razão da titularidade do domínio (v.g. IPTU). De acordo com a jurisprudência do Superior Tribunal de Justiça, o adquirente não responderá por dívidas de IPTU e outros tributos incidentes sobre a coisa, a menos que haja a respectiva advertência no edi- 
52. Será que o adquirente de um bem em hasta pública responderá pelo passivo ambiental? Será aplicável a disposição do artigo $2^{\circ} \S 2^{\circ}$ do novo Código Florestal às arrematações?

Entendemos que, pela literalidade do artigo $2^{\circ} \S 2^{\circ}$ da Lei $12.651 / 12$, o passivo ambiental é transmitido ao sucessor, "de qualquer natureza, no caso de transferência de domínio ou posse". O legislador expressamente refere o sucessor de qualquer natureza, não fazendo nenhuma distinção em relação à arrematação. Do mesmo modo, referido dispositivo legal não distingue o vício

tal de hasta pública: "Processual civil e tributário. Agravo regimental em agravo de instrumento. Execução fiscal de IPTU. Imóvel arrematado em hasta pública. Débitos tributários. Sub-rogação no preço. Parágrafo único do art. 130 do CTN. Impossibilidade de imputar-se ao arrematante encargo ou responsabilidade tributária pendente. 1. Ainda que o preço alcançado na arrematação do bem seja insuficiente para a quitação do débito tributário, o arrematante não poderá ser responsabilizado por dívidas contraídas por outrem, conforme a literalidade do parágrafo único do art. 130 do CTN. Precedente: AgRg no Ag 1246665/ SP, Rel. Min. Luiz Fux, Primeira Turma, DJ 22/04/2010, Resp 954.176/SC, Rel. Min. Eliana Calmon, Segunda Turma, DJ, 23/06/2009" (AgRg no AREsp 132083/SP, Rel. Min. Benedito Gonçalves, Primeira Turma, 28.08.2012); "Recurso especial. Tributário. Execução fiscal. IPTU. Arrematação. Edital do leilão que prevê a responsabilidade do arrematante por dívidas tributárias. Observância. Inexistência de violação do art. 130 do CTN. Recurso Especial improvido". (REsp 716438/PR, Rel. Min. Teori Albino Zavascki, Primeira Turma, 09.08.08)

52 No tocante à responsabilidade do adquirente por dívidas decorrentes de condomínio incidente sobre o imóvel arrematada, em que pese tratar-se de obrigação propter rem, a jurisprudência do Superior Tribunal de Justiça é bastante divergente, havendo entendimento tanto pela responsabilização do adquirente quanto pelo afastamento de qualquer responsabilidade do mesmo, verbis: "PROCESSO CIVIL E DIREITO CIVIL. ARREMATAÇÃO. DÉBITO DE CONDOMÍNIO. VENDA JUDICIAL COM A RESSALVA DE NÃO IMPOSIÇÃO AO ADQUIRENTE DOS PAGAMENTOS DE DÉBITOS CONDOMINIAIS. INSURGÊNCIA DO CONDOMÍNIO. DECADÊNCIA. IMPOSSIBILIDADE DE SE REPUTAR TRANSFERIDOS OS DÉBITOS. 1. A jurisprudência da $2^{a}$ Seção apresenta precedentes no sentido da responsabilidade do adquirente pelos débitos de condomínio que oneram o imóvel adquirido. Esse entendimento tem sido estendido às arrematações em juízo. 2. Na hipótese de omissão do edital quanto à existência de débitos, à precedentes na $3^{a}$ Turma que, tanto admitem, como não admitem a transferência ao adquirente dos débitos condominiais. 3. Se o condomínio, ciente de que a aquisição do imóvel em juízo for a promovida com a ressalva expressa da não transferência do débito condominial, não se insurge tempestivamente, deixando decair o seu direito à anulação do negócio jurídico, não pode, depois, reclamar do adquirente o pagamento de seu suposto crédito. 4. Não se pode onerar a parte que confiou na declaração do Poder Judiciário de não transferência dos débitos, apresentando-Ihe, anos depois da compra, uma conta de despesas condominiais em valor equivalente ao que pagou pelo bem, notadamente quando já teria precluído seu direito de invalidar o negócio jurídico, que teve a não transferência dos débitos como uma das causas determinantes. 5. A jurisprudência que entende pela transferência aos arrematantes de débitos condominiais pode, muitas vezes, inviabilizar a garantia. Na hipótese em que tais débitos se acumulem a ponto de equivaler ao valor do imóvel, nenhum licitante terá interesse em arrematar o bem, criando-se uma espiral infinita de crescimento do débito. Melhor solução seria a de admitir a venda desonerada do imóvel e a utilização do produto para abatimento do débito, entregando-se o imóvel a um novo proprietário que não perpetuará a inadimplência. 6. Recurso especial conhecido e provido". (REsp 1.299.081, Rel. Min. Nancy Andrighy, Terceira Turma, 18.09.12). 
aparente do vício oculto. Assim, qualquer sucessor responderá pelo passivo ambiental, seja ele aparente ou oculto.

Em contrapartida, o artigo 225, caput da Constituição Federal, impõe ao Poder Público e à coletividade o dever de defender e preservar o meio ambiente para os presentes e futuras gerações; e o artigo 186, inc. II, refere que a função social é cumprida quando a propriedade rural atende, dentre outros, ao requisito da utilização adequada dos recursos naturais disponíveis e preservação do meio ambiente.

Evidentemente que o artigo $2^{\circ} \S 2^{\circ}$ da Lei 12.651/12 deve ser interpretado em consonância com a Constituição Federal ${ }^{53}$. No tocante a este aspecto, os direitos fundamentais não se limitam à função precípua de serem direitos subjetivos de defesa do indivíduo contra os atos do poder público, mas também constituem decisões valorativas de natureza jurídico objetiva da Constituição, com eficácia em todo o ordenamento jurídico e que fornecem diretrizes para os órgãos legislativos, judiciários e executivos ${ }^{54}$. Não se pode esquecer que o meio ambiente é direito

53 Sobre o tema, leciona Juan María Bilbao UBILLOS ("En qué medida vinculan a los particulares los derechos fundamentales?". Constituição, Direitos Fundamentais e Direito Privado. Org. Ingo Wolfgang Sarlet. Porto Alegre: Livraria do Advogado, 2003, p. 304, verbis: "este enfoque unitário, que tende a superar el tradicional aislamiento de la Constituciónel resto del ordenamento, tiene una grantrascendencia en la medida en que impede que el Derecho constitucional y el Derecho privado puedan concebirse como compartimentos estancos, como mundos separados que discurren en paralelo y están governados por lógicas radicalmente diferentes. Eso no quiere decir, obviamente, que la Constitución se 'elhuevo cósmico jurídico', como señalara ironicamente Forsthoff. La Constitución no regula detalladamente todos los aspectos de la vida social, sólo sienta una serie de princípios básicos dotados de una especial fuerza de irradiactión. Basta una primera lectura superficial de nuestra Carta Magna para darse cuenta de que la disciplina de las relaciones jurídico-privadas se diseña ya e nel propio texto constitucional, por lo menos em sus trazos esenciales. Además, la reconstrución del ordenamento en clave constitucional implica que todas las normas del Derecho privado deben reinterpretarse a la luz de la Constitución".

54 Segundo Jorge Reis NOVAES (In: As restrições aos Direitos Fundamentais não expressamente autorizadas pela Constituição. Coimbra: Coimbra editora, 2010, 2 ed., p. 66), "a partir do momento em que, através da objectivização do conteúdo dos direitos fundamentais, se verifica uma superação do plano da estrita relação jurídica Estado/indivíduo para se passarem a considerar, também, os direitos fundamentais como valores objetivos da ordem constitucional que, enquanto tal, se devem necessariamente compatibilizar com outros valores e bens constitucionais, é toda uma nova discussão em torno dos métodos que vem suscitada no reconhecimento da dimensão objectiva dos direitos fundamentais. Com efeito, na medida em que estas novas concepções se libertam da vinculação à noção de direito subjectivo e promovem a necessidade de consideração do peso e valor relativo dos direitos fundamentais comparados com o peso dos outros bens constitucionais com que podem entrar potencialmente em colisão e, consequentemente, num relacionamento de supra e sub-ordenação, elas renovam o apelo, controverso, mas inevitável, ao recurso a metodologias de concordância prática, de ponderação e de valoração, com a abertura de 
fundamental, razão pela qual a legislação infraconstitucional deve ser interpretada no sentido de tutelar esse bem jurídico maior. Segundo Jorge Reis Novaes ${ }^{55}$,

os direitos fundamentais constituem, no seu conjunto, um sistema ou ordem objectiva de valores que legitimam a ordem jurídicoconstitucional do Estado, que condiciona constitutivamente toda a actuação dos poderes constituídos e que irradia uma força expansiva a todos os ramos do Direito.

Assim, os direitos fundamentais operam não propriamente como princípios e garantias nas relações entre indivíduos e Estado, mas se transformam em princípios superiores do ordenamento jurídico-constitucional considerado em seu conjunto, na condição de componentes estruturais básicos da ordem jurídica ${ }^{56}$.

Os direitos fundamentais produzem eficácia dirigente não apenas em relação aos órgãos estatais, mas também no tocante aos particulares. Neste contexto é que se afirma conterem os direitos fundamentais uma ordem dirigida ao Estado no sentido de que a este incumbe a obrigação permanente de concretização e realização dos direitos fundamentais. Relativamente a este aspecto, o papel do Poder Judiciário é de vital importância ${ }^{57}$. Ao tratar do tema, leciona José Carlos Vieira de Andrade ${ }^{58}$ :

novas margens de intervenção aos poderes constituídos, designadamente à justiça constitucional e a necessidade de reavaliação dos ditames clássicos da divisão dos poderes".

55 NOVAES, Jorge Reis. As restrições aos Direitos Fundamentais não expressamente autorizadas pela Constituição. p. 57.

56 Segundo Jorge Reis NOVAES (As restrições aos Direitos Fundamentais não expressamente autorizadas pela Constituição. p. 65), "há, ainda, uma objectivização, uma desvinculação dos direitos fundamentais da sua pura titularidade individual. Os direitos fundamentais passam a ser considerados enquanto fundamentos da ordem jurídica da comunidade que impregnam todo o ordenamento jurídico e a ser reconhecidos enquanto directivas constitucionais para toda actuação do poder político, designadamente do legislador".

57 A respeito do tema, leciona com precisão Lenio Luiz STRECK (In: Jurisdição Constitucional e decisão jurídica. 3. ed. São Paulo: Editora Revista dos Tribunais, 2013, p. 177-178): "... o Poder Judiciário não pode assumir uma postura passiva diante da sociedade. Na perspectiva aqui defendida, concebe-se ao Poder Judiciário (lato sensu, entendido aqui como justiça constitucional) uma nova inserção no âmbitos das relações dos poderes de Estado, levando-o a transcender as funções de checksand balances, mediante uma atuação que leve em conta a perspectiva de que os direitos construídos democraticamente - e postos na Constituição - têm precedência mesmo contra textos legislativos produzidos por maiorias eventuais. Assim, parece correta a tese de Freeman, que entende a Constituição como um instrumento da soberania democrática que não se limita e definir procedimentos para elaborar e aplicar as leis, mas organiza e qualifica estes procedimentos ordinários por forma a evitar a usurpação da soberania popular por parte de instituições públicas ou privadas".

58 ANDRADE, José Carlos Vieira de. Os direitos fundamentais - Na Constituição Portuguesa de 1976. Coimbra: Livraria Almedina, p. 144-145. 
Quando se declara que os direitos fundamentais não constituem hoje apenas 'direitos' subjetivos mas também direito objectivo, não se quer certamente com isto significar apenas que as posições jurídicas subjectivas pressupõem um preceito de direito objectivo que as preveja; isso seria afirmar uma banalidade e afirma-la até de maneira menos correcta, porque poderia dar a entender que o direito objectivo viria depois, quando a prioridade, no plano da existência, é, pela natureza das coisas, a inversa.

Pretende-se, sim, fazer ver que os direitos fundamentais não podem ser pensados apenas do ponto dos indivíduos, enquanto faculdades ou poderes de que estes são titulares, antes valem juridicamente também do ponto de vista da comunidade, como valores ou fins que esta se propõe prosseguir.

Em cada um dos direitos fundamentais, entre eles ou à volta deles, a Constituição delimita espaços normativos, preenchidos por valores ou interesses afirmados, que constituem bases de ordenação da vida social.

Contemporaneamente, a ideia de os direitos fundamentais irradiarem efeitos também nas relações privadas e não apenas constituírem apenas direitos oponíveis aos poderes públicos vem sendo considerada um dos mais relevantes desdobramentos da perspectiva objetiva dos direitos fundamentais ${ }^{59}$.

Assim, outra importante função atribuída aos direitos fundamentais e desenvolvida com base na existência de um dever geral de efetivação atribuído ao Estado, por sua vez agregado à perspectiva objetiva dos direitos fundamentais, diz com o reconhecimento de deveres de proteção do Estado, no sentido de que a este incumbe zelar, preventivamente, pela proteção dos direitos fundamentais dos indivíduos não somente contra os poderes públicos, mas também contra agressões provindas de particulares e até mesmo de outros Estados. Esta incumbência, por sua vez, desemboca na obrigação de o Estado adotar medidas positivas da mais diversa natureza, com o objetivo precípuo de proteger de forma efetiva o exercício de direitos fundamentais. Segundo Ingo Wolfgang Sarlet ${ }^{60}$,

59 SARLET, Ingo Wolfgang. A eficácia dos direitos fundamentais - Uma teoria geral dos direitos fundamentais na perspectiva constitucional. p. 148.

60 SARLET, Ingo Wolfgang. A eficácia dos direitos fundamentais - Uma teoria geral dos direitos fundamentais na perspectiva constitucional. p. 151. 
a perspectiva objetiva dos direitos fundamentais constitui, na verdade, um terreno fértil para desenvolvimentos, podendo, neste sentido, ser considerada não tanto uma função nova dos direitos fundamentais, mas, sim, fundamento para outras funções, cujos contornos e importância específica dificilmente podem ser avaliados de forma precisa e apriorística. A descoberta (ou redescoberta?) da perspectiva jurídico-objetiva dos direitos fundamentais revela, acima de tudo, que estes - para além de sua condição de direitos subjetivos (e não apenas na qualidade de direitos de defesa) permitem o desenvolvimento de novos conteúdos, que, independentemente de uma eventual possibilidade de subjetivação, assumem papel de alta relevância na construção de um sistema eficaz e racional para sua (dos direitos fundamentais) efetivação.

Por todas as razões expostas, é que a interpretação que deve ser dada ao artigo $2^{\circ} \S 2^{\circ}$ da Lei $12.651 / 12$, deve ser no sentido de interpretar-se a expressão "sucessão" em sentido amplo, abrangendo também as aquisições em sede de arrematação, preservando-se assim o direito fundamental ao meio ambiente equilibrado. Não é demasiado referir que o fato da aquisição em sede de arrematação se dar a título derivado, também serve como fundamento para este posicionamento. $\mathrm{O}$ direito de propriedade do arrematante deve sofrer restrições - responsabilidade pelo passivo ambiental - em prol da preservação do meio ambiente ${ }^{61}$.

Por derradeiro, pode-se ainda indagar: o arrematante poderá pleitear o desfazimento da hasta pública pela existência de passivo ambiental? Ou, ainda, poderá ele regressivamente buscar o ressarcimento de eventuais prejuízos sofridos? Nesta hipótese, quem seria obrigado regressivamente a ressarci-lo?

61 Ao tratar da hierarquia das normas e a supremacia dos direitos fundamentais, Claus-WiIhelm CANARIS (In: "A influência dos direitos fundamentais sobre o direito privado na Alemanha". Constituição, Direitos Fundamentais e Direito Privado. Org. Ingo Wolfgang Sarlet. Tradução de Peter Naumann), refere que: "em quase todo e qualquer ordenamento jurídico moderno, de modo mais ou menos cogente, coloca-se a questão da relação entre os direitos fundamentais e o Direito Privado. Ela radica no fato de os direitos fundamentais, enquanto parte da Constituição, terem um grau mais elevado na hierarquia das normas do que o Direito Privado, podendo, por conseguinte, influenciá-lo. Por outro lado, a Constituição, em princípio, não é o lugar correto, nem habitual para regulamentar as relações entre cidadãos individuais e entre pessoas jurídicas. Nisso consiste, muito pelo contrário, a pronunciada autonomia com relação à Constituição; e isso não vale apenas em perspectiva histórica, mas também no tocante ao conteúdo, pois, o Direito Privado, em regra, disponibilizada soluções muito mais diferenciadas para conflitos entre seus sujeitos do que a Constituição poderia fazer. Disso resulta uma certa relação de tensão entre o grau hierárquico mais elevado da Constituição, por um lado, e a autonomia do Direito Privado, por outro". 
No caso do dano ambiental ser aparente, entendemos que não há como o arrematante pleitear o desfazimento da hasta pública ou mesmo o ressarcimento de eventuais prejuízos sofridos, justamente por ter conhecimento do problema.

Todavia, em se tratando de dano ambiental oculto, ambas as indagações revelam-se pertinentes. Entendemos que o arrematante, nos termos do artigo 694 do Código de Processo Civil ${ }^{62}$, poderá pleitear, nos próprios autos, o desfazimento da arrematação com fundamento no $\S 1^{\circ}$ inciso III deste dispositivo legal, que prevê a existência de ônus real ou de gravame não mencionado no edital. Evidentemente que o passivo ambiental é um gravame que onera o imóvel.

Passado o prazo de 5 (cinco) dias, previsto no $\S 1^{\circ}$, inciso III, do dispositivo legal anteriormente mencionado, poderá o arrematante ajuizar ação autônoma (ação anulatória) com o objetivo de desfazer a hasta pública ou buscar o ressarcimento de eventual valor que for desembolsado na reparação do dano ambiental do anterior proprietário do imóvel arrematado, que continua com a responsabilidade pelo passivo ambiental, mesmo na hipótese de alienação do bem ${ }^{63}$.

62 "Art. 694. Assinado o auto pelo juiz, pelo arrematante e pelo serventuário da justiça ou leiloeiro, a arrematação considerar-se-á perfeita, acabada e irretratável, ainda que venham a ser julgados procedentes os embargos do executado. $\S 1^{\circ}$ A arrematação poderá, no entanto, ser tornada sem efeito: I - por vício de nulidade; II - se não for pago o preço ou se não for prestada a caução; III - quando o arrematante provar, nos 5 (cinco) dias seguintes, a existência de ônus real ou de gravame (art. 686, inciso V) não mencionado no edital; IV - a requerimento do arrematante, na hipótese de embargos à arrematação (art. 746, $\S \S 1^{\circ}$ e $2^{\circ}$ ); V - quando realizada por preço vil (art. 692); VI - nos casos previstos neste Código (art. 698)".

63 Neste sentido, a jurisprudência do Superior Tribunal de Justiça: "PROCESSUAL CIVIL E AMBIENTAL - AÇÃOO CIVIL PÚBLICA - DANO AMBIENTAL - CONSTRUÇÃO DE HIDRELÉTRICA - RESPONSABILIDADE OBJETIVA E SOLIDÁRIA - ARTS. 30, INC. IV, E 14, § 10, DA LEI 6.398/1981 - IRRETROATIVIDADE DA LEI - PREQUESTIONAMENTO AUSENTE: SÚMULA 282/STF - PRESCRIÇÃO - DEFICIÊNCIA NA FUNDAMENTAÇÃO: SÚMULA 284/STF - INADMISSIBILIDADE. 1. A responsabilidade por danos ambientais é objetiva e, como tal, não exige a comprovação de culpa, bastando a constatação do dano e do nexo de causalidade. 2. Excetuam-se à regra, dispensando a prova do nexo de causalidade, a responsabilidade de adquirente de imóvel já danificado porque, independentemente de ter sido ele ou o dono anterior o real causador dos estragos, imputa-se ao novo proprietário a responsabilidade pelos danos. Precedentes do STJ. 3. A solidariedade nessa hipótese decorre da dicção dos arts. 30, inc. IV , e 14, § 10, da Lei 6.398/1981 (Lei da Política Nacional do Meio Ambiente). 4. Se possível identificar o real causador do desastre ambiental, a ele cabe a responsabilidade de reparar o dano, ainda que solidariamente com o atual proprietário do imóvel danificado. 5. Comprovado que a empresa Furnas foi responsável pelo ato lesivo ao meio ambiente a ela cabe a reparação, apesar de o imóvel já ser de propriedade de outra pessoa jurídica. 6. É inadmissível discutir em recurso especial questão não decidida pelo Tribunal de origem, pela ausência de prequestionamento. 7. É deficiente a fundamentação do especial que não demonstra contrariedade ou negativa de vigência a tratado ou lei federal. 
O Novo Código de Processo Civil, no artigo 903, § $1^{\circ}$, especifica as causas que ensejam o desfazimento da arrematação, verbis:

Art. 903.

$\S 1^{\circ}$. Ressalvadas outras situações previstas neste Código, a arrematação poderá, no entanto, ser:

I - invalidada, quando realizada por preço vil ou com outro vício;

II - considerada ineficaz, se não observado o disposto no art. 802;

III - resolvida, se não foi pago o preço ou se não for prestada a caução.

De acordo com o inciso I, do $\S 1^{\circ}$, o dispositivo legal supra transcrito, é possível invalidar a arrematação em ocorrendo vício. Entendemos que o dano ambiental oculto, por ser um gravame que acaba por onerar o imóvel arrematado, consoante já exposto, é causa que enseja também à luz da nova sistemática, o desfazimento da hasta pública. A nova sistemática tratou de forma mais específica a respeito do meio processual que o arrematante dispõe para arguir o vício, diversamente do Código de Processo Civil de 1973. Nos termos do $\S 2^{\circ}$, desse mesmo dispositivo legal, "o juiz decidirá acerca das situações referidas no $\S 1^{\circ}$, se for provocado em até dez dias após o aperfeiçoamento da arrematação". Todavia, de acordo com o $\S 3^{\circ}$, "passado o prazo previsto no $\S 2^{\circ}$ sem que tenha havido alegação de qualquer das situações previstas no $\S 1^{\circ}$, será expedida a carta de arrematação e, conforme o caso, a ordem de entrega ou mandado de imissão de posse". E complementa o $\S 4^{\circ}$ que, "após a expedição da carta de arrematação ou da ordem de entrega, a invalidação da arrematação poderá ser pleiteada por ação autônoma, em cujo processo o arrematante figurará como litisconsorte necessário". De acordo com esses parágrafos respectivos, o vício poderá ser arguido nos próprios autos se o for no prazo de dez dias após o aperfeiçoamento da arrematação, que se

8. Recurso especial parcialmente conhecido e não provido. (REsp 1056540/GO, Relatora Ministra Eliana Calmon, T2 - Segunda Turma, Data do Julgamento 25/08/2009, Data da Publicação 14/09/2009)." 
dá com a assinatura do auto. Após este prazo, o arrematante ainda dispõe da possibilidade de ajuizamento de uma ação anulatória.

\section{CONSIDERAÇÕES FINAIS}

A responsabilidade civil pela reparação do dano ambiental tem como finalidades principais: reduzir os riscos ambientais e incentivar as medidas de prevenção de danos ambientais.

Em prol da efetivação da proteção ao meio ambiente, em algumas situações haverá a incidência da responsabilidade civil sobre pessoa que não causou o risco ou o dano ambiental, como é o caso de adquirente de imóvel em reserva florestal desmatada pelo antigo proprietário.

Assim, a interpretação que deve ser dada ao artigo $2^{\circ} \S 2^{\circ}$ da Lei $12.651 / 12$, deve ser no sentido de interpretar-se a expressão "sucessão" em sentido amplo, abrangendo também as aquisições em sede de arrematação, preservando-se assim o direito fundamental ao meio ambiente equilibrado. O direito de propriedade do arrematante deve sofrer restrições - responsabilidade pelo passivo ambiental - em prol da preservação do meio ambiente.

No caso do dano ambiental aparente não há como o arrematante pleitear o desfazimento da hasta pública ou mesmo o ressarcimento de eventuais prejuízos sofridos, justamente por ter conhecimento do problema.

Todavia, em se tratando de dano ambiental oculto, poderá o arrematante, nos termos do artigo 694 do Código de Processo Civil ${ }^{64}$, pleitear, nos próprios autos, o desfazimento da arrematação com fundamento no $\S 1^{\circ}$ inciso III deste dispositivo

64 "Art. 694. Assinado o auto pelo juiz, pelo arrematante e pelo serventuário da justiça ou leiloeiro, a arrematação considerar-se-á perfeita, acabada e irretratável, ainda que venham a ser julgados procedentes os embargos do executado. $\S 1^{\circ}$ A arrematação poderá, no entanto, ser tornada sem efeito: I - por vício de nulidade; II - se não for pago o preço ou se não for prestada a caução; III - quando o arrematante provar, nos 5 (cinco) dias seguintes, a existência de ônus real ou de gravame (art. 686, inciso V) não mencionado no edital; IV - a requerimento do arrematante, na hipótese de embargos à arrematação (art. 746, $\S \S 1^{\circ}$ e $2^{\circ}$ ); $V$ - quando realizada por preço vil (art. 692); VI - nos casos previstos neste Código (art. 698)". 
legal, que prevê a existência de ônus real ou de gravame não mencionado no edital. Evidentemente que o passivo ambiental é um gravame que onera o imóvel. Vencido o prazo previsto neste dispositivo legal, poderá o arrematante buscar o desfazimento da hasta pública por meio do ajuizamento de uma ação anulatória.

\section{REFERÊNCIAS}

ADAMEK, Marcelo Vieira Von. Passivo Ambiental. Direito ambiental em evolução - n. 2. Vladimir P. Freitas (Org). 1. ed., $3^{a}$ tir., Curitiba: Juruá, 2002.

ANDRADE, José Carlos Vieira de. Os direitos fundamentais - Na Constituição Portuguesa de 1976. Coimbra: Livraria Almedina, 2012.

ANTUNES, Paulo de Bessa. Direito ambiental. 11. ed. Rio de Janeiro: Lumen Juris, 2008.

ASCENÇÃO, José de Oliveira. As relações jurídicas reais. Lisboa: Livraria Morais, 1962.

ASSIS, Araken de. Manual da Execução. 11. ed. São Paulo: Revista dos Tribunais, 2007.

CALAMANDREI, Piero. La sentencia como acto de ejecución forzada. Estudios sobre el processo civil. Tradução de Santiago Sentis Melendo. Buenos Aires: EBA, 1945.

CAMPEIS, Giuseppe; PAULI, Arrigo de. Le esecuzioni civili - Procedimenti ordinari e speciali. CEDAM, 2007.

CANARIS, Claus-Wilhelm. "A influência dos direitos fundamentais sobre o direito privado na Alemanha". Constituição, Direitos Fundamentais e Direito Privado. Org. Ingo Wolfgang Sarlet. Tradução de Peter Naumann. Porto Alegre: Livraria do Advogado, 2003.

CANÇADO TRINDADE, Antônio Augusto. Direitos humanos e meio ambiente: paralelo dos sistemas de proteção internacional. Porto Alegre: Fabris, 1993.

CARNELUTTI, Francesco. Sistema de derecho procesal civil. Vol. 3, n. 437, p. 131-133. Tradução de Niceto Alcalá-Zamora y Castillo e Santiago Sentis Melendo. Buenos Aires: UTEHA, 1944, Vol. 3.

CARVALHO, Délton Winter de. Dano Ambiental Futuro - A responsabilização civil pelo risco ambiental. Porto Alegre: Livraria do Advogado, 2013.

CHIOVENDA, Giuseppe. Sulla natura giuridica dell'espropriazione forzata, Saggi di diritto processual e civile. Milano: Giuffrè, 1993, Vol. 2. 
BETIOL, Luciana Stocco. Responsabilidade civil e proteção ao meio ambiente. Saraiva, 2010.

BOBBIO, Norberto. A Era dos Direitos. 10. ed. Rio de Janeiro: Campus, 1992.

BONAVIDES, Paulo. Curso de Direito Constitucional. 29. ed. São Paulo: Malheiros Editores, 2014.

DESTEFENNI, Marcos. A Responsabilidade Civil Ambiental e as Formas de Reparação do Dano Ambiental. São Paulo: Bookseller, 2005.

GAVIÃO FILHO, Anízio Pires. Direito Fundamental ao Ambiente. Porto Alegre: Livraria do Advogado, 2005.

LAFER, Celso. A reconstrução dos direitos humanos: um diálogo com o pensamento de Hannah Arendt. São Paulo: Companhia das Letras, 1998.

LEMOS, Patrícia Faga Iglecias. Meio ambiente e responsabilidade civil do proprietário. São Paulo: Editora Revista dos Tribunais, 2008.

LIEBMAN, Enrico Tullio. Processo de execução. São Paulo: Saraiva, 1968.

LOURENÇO, Paula Meira. A função punitiva da responsabilidade civil. Coimbra: Coimbra Editora, 2006.

MACHADO, Paulo Affonso Leme. Direito ambiental brasileiro. 9. ed. São Paulo: Malheiros, 2001, p. 49.

MARINONI, Luiz Guilherme; ARENHARDT, Sérgio Cruz. Execução. São Paulo: Editora Revista dos Tribunais, 2007.

MILARÉ, Édis. Princípios fundamentais do direito do ambiente. Revista dos Tribunais, Ano 87. V. 756, Outubro de 1998.

MONTENEGRO, Magda. Meio Ambiente e Responsabilidade Civil. São Paulo: IOB, Thomson, 2005.

NOVAES, Jorge Reis. As restrições aos Direitos Fundamentais não expressamente autorizadas pela Constituição. 2. ed. Coimbra: Coimbra editora, 2010.

PEREIRA, Caio Mário da Silva. Instituições de Direito Civil - Teoria Geral das Obrigações, VI. Atualizador: Guilherme Calmon Nogueira da Gama. Rio de Janeiro: Editora Forense, 2006.

PUGLIATTI, Salvatore. Esecuzione forzata e diritto sostanziale. Milano: Giuffrè, 1935 - XIII. Casi speciali di esecuzione. Padova: CEDAM, 1998. 
RANGEL, Paulo de Castro. Concertação, Programação e Direito do Ambiente. Coimbra: Coimbra Editora, 1994.

SALLES, Carlos Alberto de. A obrigação propter rem do proprietário pela recuperação do solo degradado. In: Francisco de Asís Palacios Criado, Marcelo Augusto Santana de Melo, Sérgio Jacomino. (Org.). Registro de imóveis e meio ambiente. São Paulo: Saraiva, 2010.

SARLET, Ingo Wolfgang. A eficácia dos direitos fundamentais - Uma teoria geral dos direitos fundamentais na perspectiva constitucional. Porto Alegre: Livraria do Advogado, 2012.

SARLET, Ingo Wolfgang e FENSTERSEIFER, Tiago. Direito Constitucional Ambiental Constituição, Direitos Fundamentais e Proteção do Ambiente. 4. ed. São Paulo: Editora Revista dos Tribunais, 2014.

SATTA, Salvatore. L'esecuzione forzata. 3. ed. Turim: UTET, 1954.

STEIGLEDER, Annelise Monteiro. Responsabilidade civil ambiental. As dimensões do direito ambiental no direito brasileiro. 2. ed. rev., atual. e ampl., Porto Alegre: Livraria do Advogado, 2011.

STRECK, Lenio Luiz. Jurisdição Constitucional e decisão jurídica. 3 ed. São Paulo: Editora Revista dos Tribunais, 2013.

UBILLOS, Juan María Bilbao. Em qué medida vinculan a los particulares los derechos fundamentales? Constituição, Direitos Fundamentais e Direito Privado. Org. Ingo Wolfgang Sarlet. Porto Alegre: Livraria do Advogado, 2003.

ZANZUCCHI, Marco Tullio. Diritto Processuale Civile. 4. ed. Vol. 3. Milão: Giuffrè, 1946.

Recebido em: mar/2015

Aprovado em: jun/2015 